\title{
Evaluation of Digital Media Usage of Women through Motherhood Models as a Cultural Ideology

\author{
Derya Gül Ünlü
}

\author{
Dr.Öğretim Üyesi \\ İstanbul Üniversitesi Illetişim Fakültesi \\ Halkla İlişkiler ve Tanıtım Bölümü \\ Araştırma Yöntemleri Anabilim Dalı \\ derya.gul@istanbul.edu.tr \\ Orcid: 0000-0002-3628-715X
}

\begin{abstract}
Widespread use of internet and mobilization of digital means of communication came with several transformations in the social structure. One of the most important transformations in this sense is individuals, starting to participate in digital communication by utilizing digital communication tools. As digital content, generated in these media are shared and popularised, readers with access to this content come up with new information or suggestions, which are related to their parenting roles and can make use of said content according to their needs. In this regard, investigating the digital transformation of the communication of parents with each other, as well as that with their children based on the mothering role, which is not independent of the cultural codes of social structure, is considered to be important. Since motherhood is not only an act of giving birth, but also a social role with cultural implications attached; revealing the differentiation in individual tendencies to use digital communication media according to the mothering model they adopt is also important. To that end, this study aims to investigate maternity roles and how women, who assume this role participate in digital communication processes, thus understanding the cultural transformation, which is also a by-product of digital communication process. In line with this objective, semi-structured face-to-face interviews were carried out with 16 mothers, who adopted 2 different mothering roles (gendered talent/conscious collaboration). Consequently, the study found that the age range of children is a determinant in the way, in which mothers use digital communication tools, and women, who adopt mothering as collaboration, use both their social media accounts and mobile applications more actively, com-
\end{abstract}

DOI:10.16878/gsuilet.658080 
pared to women, who assume the other mothering role. This study is thought to carry significance in terms of evaluating women's practices, which are categorized as 'motherhood models', based on the duties and responsibilities that are shouldered within the family, over involvement in and utilization of digital communication settings.

Key Words: Digital communication, gender, motherhood, digital motherhood, cultural ideology.

\section{Evaluation de l'utilisation des médias numérique des femmes par le biais de modèles de mère comme une idéologie culturelle}

\section{Résumé}

L'utilisation généralisée d'Internet et la mobilisation des moyens de communication numériques ont entraîné plusieurs transformations de la structure sociale. Parmi les transformations les plus importantes, il existe le fait de participation aux médias numériques en utilisant des outils de communication numériques. Les contenus numériques créés sur ces supports étant partagés et vulgarisés, les lecteurs qui y ont accès proposent de nouvelles informations ou suggestions relatives à leurs rôles parentaux et peuvent les utiliser en fonction de leurs besoins. À cet égard, il est jugé important d'étudier la transformation numérique de la communication des parents entre eux et avec leurs enfants sur la base du rôle de mère, qui n'est pas indépendant des codes culturels de la structure sociale. Car la maternité est non seulement un acte d'accouchement, mais aussi un rôle social ayant des implications culturelles. Par conséquent, il est également important de révéler la différenciation de leurs tendances à utiliser les médias de communication numériques en fonction du modèle de maternité qu'ils adoptent. À cet égard, l'étude vise également à étudier le rôle de la maternité et la manière dont les femmes qui en assument participent au processus de communication numérique afin de comprendre la transformation culturelle, qui est également un sous-produit du processus de communication numérique. Conformément à cet objectif, des entretiens en face à face semi-structurés ont été menés avec 16 mères qui ont adopté 2 rôles de mère différents (talent sexué / collaboration consciente). A la suite de la recherche, il a été découvert que la tranche d'âge des enfants était un facteur déterminant dans la manière dont les mères utilisent les outils de communication numériques, et les femmes qui adoptent la maternité en tant que collaboration utilisent leurs comptes de médias sociaux et leurs applications mobiles plus les femmes qui adoptent l'autre rôle de mère.

Mots clés: Communication numérique, genre, maternité, maternité, idéologie culturelle. 


\section{Kültürel Bir İdeoloji Olan Annelik Modelleri Üzerinden Kadınların Dijital Medya Kullaniminin Değerlendirilmesi}

\section{Öz}

Internetin yaygın kullanımı ve dijital iletişim araçlarının mobilleşmesi sosyal yapıdaki birçok dönüşümü de beraberinde getirmiştir. Bu dönüşümlerin en önemlilerinden biri ise, bireylerin ebeveynlik pratikleri için dijital iletişim araçlarından yararlanarak, dijital iletişim ortamlarında yer almaya başlamaları olmuştur. Söz konusu ortamlarda üretilen dijital içeriklerin paylaşılması ve yaygınlaştııılmasıyla birlikte, bu içeriğe ulaşan okuyucular, kendi ebeveynlik rollerine dair yeni bilgiler ya da önerilerle karşılaşmakta ve ihtiyaçları doğrultusunda bu içeriklerden yararlanabilmektedirler. Bu bakımdan, ebeveynlerin hem kendi aralarında hem de çocuklarıyla olan iletişiminin dijital dönüşümünün, içeriği toplumsal yapının kültürel kodlarından bağımsız olmayan annelik rolü üzerinden incelenmesinin de önem taşıdığı düşünülmektedir. Çünkü annelik, sadece doğurmakla ilgili bir edinim değil, aynı zamanda kültürel içerikli bir toplumsal roldür dolayısıyla kadınların benimsedikleri annelik modeline bağı olarak, dijital iletişim ortamlarını kullanım eğilimlerindeki farklılaşmanın ortaya koyulması da önem taşımaktadır. Bu bakımdan çalışma kapsamında, dijital iletişim sürecinin de bir getirisi olan kültürel dönüşümün anlaşılabilmesi için, annelik rolü ve bu rolü benimseyen kadınların dijital iletişim sürecinde yer alma pratiklerinin de incelenmesi hedeflenmektedir. Bu amaç doğrultusunda, Cowdery 2 farklı annelik modelini (cinsiyetlendirilmiş yetenek/bilinçli kolaborasyon) benimsemiş 16 anne ile yarı yapılandırılmış yüz yüze görüşmeler gerçekleştirilmiştir. Araştırma sonucunda ise, annelerin dijital iletişim araçlarından yararlanma biçimlerinde çocuklarının yaş aralığının belirleyici olduğu, anneliği bir iş birliği olarak benimsemiş kadınların, diğer annelik modelini benimsemiş kadınlara göre, hem sosyal medya hesaplarını hem de mobil uygulamaları daha aktif olarak kullandıkları tespit edilmiştir. Söz konusu çalışmanın, aile içerisinde üstlenilen görev ve sorumluluklara dayalı olarak 'annelik modeli' olarak kategorize edilen kadın pratiklerini, dijital iletişim ortamlarına dahil olma ve yararlanma biçimleri üzerinden değerlendirmesi bakımdan önem taşıdığı düşünülmektedir.

Anahtar Kelimeler: Dijital iletişim, toplumsal cinsiyet, annelik, dijital annelik, kültürel ideoloji. 


\section{Introduction}

The notion of individuals, starting to participate in digital communication processes, also within the context of parenting roles, was accompanied by the production of a large number of content, related to parenting practices in digital media. Along with the sharing and dissemination of these digital contents, readers with access to this content started to encounter new information or suggestions related to their own parenting roles. In this respect, it is considered that digital transformation of parents' communication with each other and with their children are also of great significant for the role of motherhood, the content of which is not independent of the cultural codes of social structure. That is because mothering is not only an act related to giving birth, but also a social role with cultural content, and the motherhood role adopted by the woman is an important determinant for each individual joining the society, especially until said individual reaches a specific age. Therefore, it is also of importance to analyse the motherhood roles in women's ways to participate in digital communication processes, according to the motherhood role they adopt in order to understand the cultural transformation, which is one of the advantages of digital communication process.

From this perspective, the study aims to determine ways of women, who adopted the role of motherhood, with regard to the participation in digital communication processes, and reveal whether practices of participating in digital communication processes differ according to the adopted motherhood model. With an analysis conducted based on two different models, the study aims to develop a profile related to mothers' tendencies to participate in digital communication and use digital media according to the content of roles they adopt within the family. In line with the aim of the study, first, motherhood role as a cultural ideology and definitions of two mothering models with regard to the content of motherhood role as suggested by Knudson and Martin (2005) are addressed. Afterwards, findings of the study, which were collected through semi-structured interviews conducted, are provided in a comparative manner, based on two different motherhood models adopted by mothers. It is hoped that this study will contribute to understanding women's tendencies to participate in digital communication processes as a result of adopting their motherhood roles, which are socially constructed phenomena rather than a mere physical process, experienced by women.

\section{Motherhood as a Cultural Ideology}

Motherhood is defined as an idea related to femininity and gender (Arendell, 2000) and a natural action, which helps society to reproduce its cultural ideologies (Baber and Allen, 1995). On the other hand, according to Collin and Laborie $(2015$, p.39) motherhood represents both a valued specificity, that is, the capacity of giving birth to a being, a social function, for which political or social 
rights can be requested, and one of the sources of repression. From this point of view, motherhood is not only an individual experience, but it also involves a social expectation, and the necessity of meeting a social expectation manifests as a reason for the reproduction of the domination on each woman, who is assumed to have or will assume the role of motherhood. Therefore, the content of the concept of motherhood becomes evident within the framework of the distinction between becoming a mother as an individual act, and mothering as a social expectation. Miller $(2005$, p.3) explains these two practices related to motherhood, which take place on individual and social levels, as follows:

"'Mothering' refers to the personal, individual experiences that women have in meeting the needs of and being responsible for their dependent children. 'Motherhood', on the other hand, refers to the context in which mothering takes place and is experienced. The institution of motherhood in the Western world is, then, historically, socially, culturally, politically, and, importantly, morally, shaped."

It is observed that many studies, which examine the structuring of motherhood role within the society as a social practice, address motherhood as an ideology shaped by the socio-cultural structure (Baber and Allen, 1995; Badinter, 1981; Barak-Brandes, 2017; Bernard, 1974; Hays, 1996; Johnson and Swanson, 2003; Ribbens, 1994; Rich, 1995; Stearney, 1994). That is because the role of motherhood is associated with "the 'nature' of femininity in accordance with the sexist perspective, and attributed to women as a 'self-sacrificing cover' by the patriarchal system" (Bal, 2014, p.61-62). In these motherhood roles, which are constructed according to the expectations of patriarchal societies, only positive behavioural patterns are seen, and interests of women are associated with those of mothers, while interests of children are associated with those of mothers too (Collin and Laborie, 2015, p.43). In other words, a mother who takes good care of, feeds and raises her child is both an 'agreeable' mother and an 'agreeable' woman. The secret to being a good mother depends on the extent to which child care is undertaken successfully. Therefore, meeting the needs of the child in the best way, means acting in accordance with the interests of mothers. On the other hand, this interwoven relationship between femininity and motherhood excludes fathers from the task of childcare, all the responsibilities assumed due to role of motherhood are posited within the domain of women. This parenting system, which is assumed by women and men unequally, contributes to the continuity of the asymmetrical structure of gender based division of labour. In this parenting system, in addition to biological motherhood, socio-cultural motherhood is also constructed as a female role and this constitutes one of the basic sources of gender inequality. In this respect, all women, who undertake the role of motherhood, take on a significant task for the reproduction of patriarchal society's ideology.

Rather than being an instinct, stemming from the nature of women, the role of motherhood is considered as a social construct, which is dictated by so- 
ciety on the individual, and which also emerges with the expectations of society (Badinter, 1981; Marshall, 1991; Phoenix and Woollett, 1991; Tardy, 2000). Therefore, the motherhood experience is described as a set of social interaction, which is shaped within the gendered relationship networks and social institutions in a given time and space (Arendell, 2000; Glen, 1994; Thompson and Walker, 1989). However, declining motherhood as a feminine instinct and a constituent of women's biological structure, contrary to traditional and popular belief, requires thinking why only women undertake motherhood practices and why fathers (i.e. men) remain in the background in this process. This idea brings along the questioning of the supracultural ideology, which is the product of patriarchal society, and suggests that motherhood is an integral aspect of female identity, resulting from the nature of women. Many studies addressing the ideology of motherhood and social practices, which become prominent as part of this ideology (Elvin-Nowak and Thompson, 2001; Glenn et.al., 1994; Hays, 1996) emphasize the fact that the undertaken role of motherhood shapes the life experiences of women. The most significant underlying reason is the motherhood myth, which is idealized by the patriarchal social structure for women. According to Stearney (1994) the motherhood myth created in patriarchal societies idealizes and ${ }^{1}$ romanticises the experience of motherhood and the perception about motherhood role as a mandatory role, which is completely independent of cultural boundaries. On the other hand, Barak-Brandes (2007, p.59) emphasize the fact that the core of patriarchal ideology assigns women roles, which result from their biological nature, and require taking care of children, devoting oneself to domestic tasks, thereby overcoming these responsibilities. In this regard, it would not be wrong to argue that this role, which is attributed by social structure to motherhood, constitutes one of the bases, on which gender inequality is maintained. Continuous reproduction of this motherhood ideology meets the needs of patriarchal society, maintains it and restricts the social existence of women; for women make physical, emotional and economic sacrifices to provide the ideal childcare for the sake of 'a good motherhood' and regard this as an integral part of their existence. Therefore, it can be suggested that, much like the social content attributed to gender, the motherhood ideology, which is based and imposed upon women, is also constructed by the social structure.

While motherhood is considered as one of the significant constituents, which ensure the continuity of the production of socio-cultural ideology, the fact

1 Apart from the emphasis on women's undertaking motherhood experience due to their biological nature, it is necessary to address developments in reproductive technologies. It is observed that the experience of becoming a mother and father is shaped thanks to these technological developments. This also ambiguates the definitions related to paternity bonds and the distinction between biological and symbolic. For instance, in an artificial insemination scenario with the sperm of a donor, the father is not the donor. On the other hand, in surrogate motherhood scenarios, the father gives the sperm, but the mother who gives birth to the child will not be the legal mother. This mother will be the wife of the person, who provides his sperm. Artificial insemination, which is achieved by giving ovula, paves the way for making a distinction between genetic mother and uterine mother. When 'social mothers' who adopt and raise the child are added to this list, we can classify motherhood into three categories (Collin and Laborie, 2015, p.44). 
that parenthood roles shared in each family may not be exactly the same with each other must also be addressed. Sharing of parenthood roles, contents and expectations attributed to these roles in question may be different due to differences in social structure and demographic characteristics of family members. Also, parenthood is a form of being involved in interpersonal emotional relations rather than a set of instinctively known and simply expressed behavioural patterns (Erdoğan, 2008, p.77). Considering the fact that individuals take part in various interpersonal interaction processes, based on the parenthood roles they assume, it is not surprising to observe different motherhood and fatherhood roles as adopted by individuals. In this context, this study aims to determine how and for which purposes women, who assume different motherhood models, participate in digital communication processes within the framework of motherhood practices, as well as the similarities and differences of the ways women use digital media.

\subsection{Mothering: Is a Gendered Talent? Or Is It a Conscious Collaboration?}

It is possible to list many examples of studies, which define mothering models based on different variants according to the practices of assuming mothering roles within the family (Budig et.al., 2012; Christopher, 2012; Dreuth, 2003; McDonagh, 2002; Naples, 1992; Thomson et.al., 2001). In the study conducted by Cowdery and Knudson-Martin (2005), it was found out that there are two different mothering models according to the duties-responsibilities defined by parents within the context of mothering role and how they share parenting roles. Within this framework, in this study, which investigates the practices of participating in digital communication according to the mothering roles assumed by mothers, it was considered appropriate to investigate this subject based on two different mothering models defined by Cowdery and Knudson-Martin (2005).

\section{Mothering as a Gendered Talent}

This mothering model is generally observed among traditional couples, who accept mothering as a talent, which is acquired by woman inherently. The division of labour between these couples is structured according to gender relations and man and woman assume various behavioural patterns within the framework of roles, which are 'appropriate for their genders'. Mothers who adopt this model are primary undertakers of responsibilities related to child care due to their gender. This brings along a direct, close and strong relationship between the mother and the child, which is built mostly on childcare. On the other hand, fathers do not actively participate in this process and take on a secondary position since they take less responsibility. The fact that fathers participate in the childcare process less, causes an indirect and more distant relationship with the child, which is established through the mother. 
Figure 1: Mothering as a gendered talent (Cowdery and KnudsonMartin, 2005, p.339).

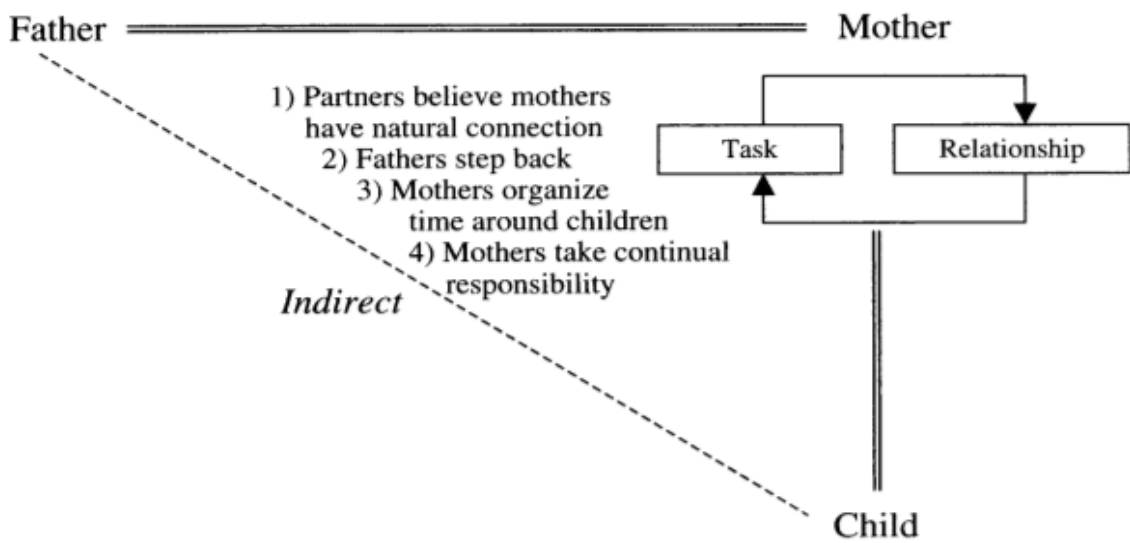

In this model, the way, in which the relationship of parents with the child, is differentiated according to the mothering role assumed, which can be explained via the following steps (2005, p.339-340):

1) Partners believe that mothers have a natural connection and knowledge: It is assumed that women have a natural talent when it comes to childcare. Since they give birth, women establish a special bond with their children and know what children need.

2) Fathers step back: Especially in the early periods after the child joins the family, fathers believe that they do not possess the necessary talent and feel insufficient. This is because it is assumed that mothers are in an instinctive relationship with their children. Therefore, fathers transfer their responsibilities related to the mothers, whose competence they accept, and reduce their childcare responsibilities.

3) Mothers organize their time around children: Another reason as to why children take a more active role in the childcare process is the popularity of the idea that women have more time to meet the needs of the child. Accordingly, the parent to take care of the child in division of labour within the family is determined according to which one of the parents is more available. Also, in this process, the fact that fathers remain in the back ground, causes mothers to allocate more time to take care of their children.

4) Mothers take continual responsibility: The division of labour between couples, who adopt this motherhood model is structured in a way that responsibilities for the effort, related to childcare and their management, is assigned to the mother. Therefore, in such family structures, mothers assume almost all the responsibilities of the child, as a 
result of which the direct bond they establish with their children grows stronger.

\section{Mothering as a Conscious Collaboration}

According to the motherhood model in which motherhood is regarded as a conscious collaboration, parents assume responsibilities at equal levels in all processes related to childcare. In non-traditional (post-gender) families, which do not adopt a division of labour based on gender, fathers want to take responsibility in childcare as much as the mothers, and share responsibilities related to childcare with women. Therefore, in these family structures, motherhood is regarded by couples not as a female role but as duties shared by both men and women.

Figure 2: Mothering as a conscious collaboration (Cowdery and Knudson-Martin, 2005, p.340).

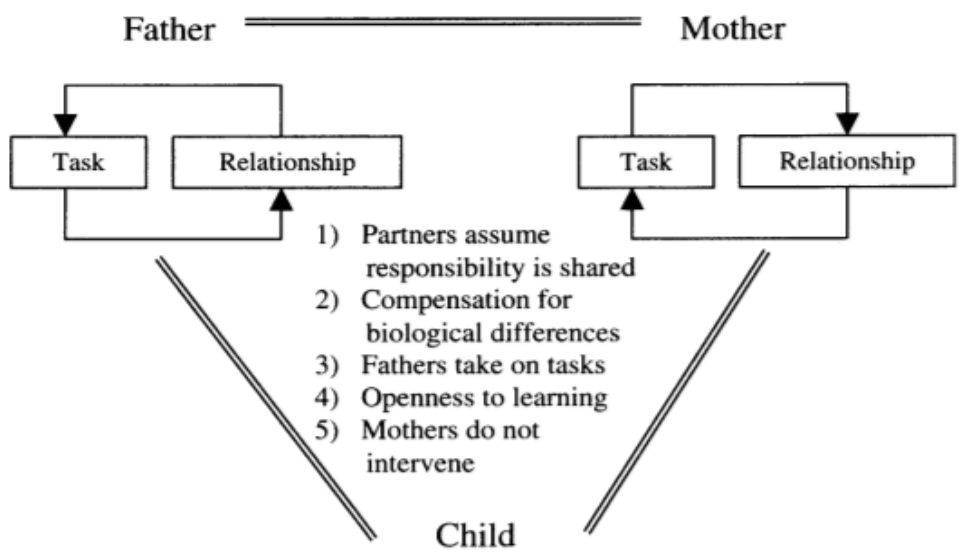

In this model, both the mother and the father assume responsibility for the child on equal levels. This collaboration between the couple ensures that both parties establish a direct bond with the child. In this context, Cowdery and Knudson-Martin explain parents' establishment of a direct relationship with their children over the following steps (2005, p.340-341):

1) Partners' assumed responsibility is shared: In families, where structure motherhood role is a collaboration, it is accepted that responsibilities related to the child are assumed by the mother and the father equally.

2) Compensated for biological differences: Biological differences between post-gender couples do not prevent them from taking responsibilities towards their children equally. In these families, 
parents seem to develop various strategies to assume tasks, related to children, equally.

3) Fathers take on tasks: Post-gender fathers consider themselves responsible for the care of their children at least as much as the mothers. Therefore, fathers do not establish an indirect relationship with the child through the mother and mothers do not feel themselves responsible for fixing fathers' relations with the child in such family structures.

4) Open to learning: Post-gender parents exchange information about childcare with each other. Therefore, fathers play an active role in meeting the child's needs. This participation by the fathers can also be observed when meeting the requests and expectations of their partners. In addition, being open to learning is important in terms of constituting a basis for parents to develop new and nongendered talents.

5) Mothers do not intervene: As far as post-gender parents, who collaborate and learn from each other, are concerned, mothers do not intervene in fathers, who are willing to take roles in family affairs. On the other hand, fathers, who are not watched over by mothers, can develop the direct relationship they establish with their children by taking more responsibilities for the child care.

\section{Digitalization of Motherhood}

It is possible to posit that along with the popularization of digital means of communication, women started to conduct their motherhood practices also via digital media and to use digital communication tools both in domestic communication and in their communication processes with other parents, in accordance with the motherhood roles they assume. The production of digital content related to parenting increased as a result of the inclined use of digital media by parents and their relevant purposes of usage. Nowadays, it is known that there are web pages, blogs, social media accounts, online message applications and mobile applications, which only provide content about parenting roles and lots of content related to various motherhood practices are shared and discussed with other mothers on these digital media. Moreover, digital media provides multiple functions for accessing various content related to different purposes and needs in the process of women's fulfilling of their motherhood practices.

Websites and forums are among the leading items of the said digital communication media. They are important in that they are media on which highly personal content (women's expectations from motherhood, the problems they have with their partners during pregnancy, disappointments about their new roles and so on.) are shared (Lupton and Pedersen, 2016; Pedersen and Lupton, 2016). That is because these digital media allow women to communicate anonymously 
with others, who go through the same things with them, and receive information and advice from women, who encountered the same problems. Thanks to this user anonymity, women can share their expectations, criticisms about other family members and particularly their partners, and the problems they have with each other, without disclosing information about their identities (Madge and O'Connor, 2006; Pedersen, 2014; Schoenebeck, 2013). Thus, mothers can both reach the information and social support they seek, and also take part in a platform, where they can relax by having an exchange of ideas about various problems. Much like web pages and online forums, blogs are also among digital media, where mothers share their own experiences with others, and get information and advice. Mothers, who write blogs, convey their own experiences in the form of an autobiography, and they may recommend various products or services depending on the subject matter. It is seen that various research studies addressing motherhood blogs consider such blogs as a community and media, which allow the presentation of an identity, through which the tension between women's own identity and the motherhood they assumed can be negotiated (Gibson and Hanson, 2013; Morrison, 2010). In addition to blogs, e-mail, mobile phones and online messaging applications are also among digital media, which are used for various motherhood practices such as collecting information and communicating with children. Specifically with the popularization of mobile phones, the possibility of communicating with several people simultaneously at any time and place without restrictions, facilitated and expedited the communication process the mothers establish with each other, with their partners and with their children. Hence, women, who have the possibility to communicate online instantly by means of the digital media, reinforced their family bonds, and had the opportunity to achieve the emotional output they aimed by being in touch with their children continuously (Longhurst, 2016, p.120). On the other hand, mothers who have children of young age, had the chance to use digital media for their own needs while taking care of their children at the same time (Gibson and Hanson, 2016; Lupton, 2016). This prevents mothers from becoming distant from their own social surroundings and feeling isolated, thereby providing a psychological support to the mothers. In this context, mobile phones are defined as tools, which help mothers "get through the day" (Bradley and Guerin, 2010).

One of the most important factors, which allows mothers to communicate with other members of the family continuously, is the opportunity to interact with other family members through their social media accounts. Today, individuals use social media sites for several different purposes within the framework of parenting practices, such as information exchange, getting support for various problems they encounter or providing support to others, having an exchange of ideas with other parents going through the same problems or with experts, and sharing information and developments related to their children (Ammari et.al., 2014; Cesar et.al., 2018; Drentea and Moren-Cross, 2005; Dworkin et.al., 2013; Gibson and Hanson, 2013; Lupton, 2016; Lupton and Pedersen, 2016; Madge and O'Connor, 2006; Morris, 2014; Walker et.al., 2011). Social media 
sites, which have features different from each other, are often preferred by parents for sharing photographs of their children, sharing the development or school achievements of their children or ideas or concerns about parenting. Such posts shared by individuals on social media sites also make it easier for them to establish relationships with other parents, their parents and relatives, while strengthening and extending these relationships, thus, possessing a strong social capital (Archer and Kao, 2018; Jang and Dworkin, 2014; Young, 2011). It was also determined that, among many different social media accounts, parents use Facebook more frequently than the others (Ammari and Schoenebeck, 2015; Ammari et.al, 2015; Gibson and Hanson, 2013; Lupton and Pedersen, 2016; Morris, 2014). As far as studies investigating the reasons as to why mothers prefer Facebook are concerned, it can be suggested that especially the mothers who have children of younger ages use Facebook for the purpose of sharing their personal experiences related to motherhood on group pages, and communicating with others, who feel like them (Gibson and Hanson, 2013; Lupton, 2016; Lupton and Pedersen, 2016; Morris, 2014; Robinson et.al., 2019). In addition to this, it is observed that mothers prefer Facebook also for announcing their pregnancies and developments throughout their pregnancies with their family members and friends (Ammari et.al., 2015; Bartholomew et.al., 2012; Morris, 2014). On the other hand, limited number of studies, which investigate mothers' and pregnant women's purposes of using other social media, were also identified. Among these are research studies, which address the ways pregnant women share their pregnancy on Instagram (Eagle, 2019; Tidenberg, 2015; Yam, 2019) or how YouTube is used by mothers as a source of information (Keelan et. al., 2007).

Finally, mobile applications provided to the use of mothers should also be mentioned at this point. There are several mobile applications, which provide several different content, which can be used for motherhood practices. For instance, there are myriad applications, through which pregnant mothers can follow the development of their babies on a daily basis, women who would like to become pregnant can calculate their ovulation periods, keep nutrition and sleep calendars for their children after birth, shop for their children or keep track of their weight loss after birth. In this context, it is observed that especially pregnancy applications are preferred more than the other applications (e.g. fitness-related applications) (Dolan, 2013). Mothers prefer these applications over the others, because most women regard applications related to motherhood and pregnancy as information sources and functional tools that provide support to them during this process, since they can be easily and instantly accessed via mobile phones, thanks to their convenient format (Hearn et.al., 2013; Johnson, 2014; Kraschnewski, 2014; Lagan et.al, 2010; Lupton, 2016; Lupton, 2017; Lupton and Pedersen, 2016; O'Higgins et.al., 2015). 


\section{Research Process}

The research process of the study, which aims to determine the ways, in which women participate in digital communication processes and make use of digital means of communication according to the motherhood model they adopt in the family, is explained in detail below.

\section{Aim of the Research and Research Questions}

The research portion of study aims to determine the ways, in which women participate in digital communication processes and make use of digital means of communication within the framework of motherhood roles, and whether their tendencies to participate in digital communication processes differ according to different motherhood roles. To that end, a profile is created about how mothers participate in digital communication and use digital means of communication according to the content of the roles they adopt within the family, with an analysis to be conducted on two motherhood models. In accordance with this aim, research questions addressed within the scope of the study are as follows:

RQ1: How do women make use of digital means of communication for their motherhood roles? How does the way women make use of digital means of communication for motherhood roles, according to the motherhood model they adopt?

R02: Do women use social media accounts for motherhood roles? Do social media accounts preferred by women, who participate in social media within the scope of their motherhood roles and their purposes of using these accounts differ according to the motherhood model they adopt?

RQ3: For which needs do women prefer mobile applications within the framework of motherhood roles? Do the ways in which women use mobile applications and their preferences differ according to the motherhood model they adopt?

\section{Research Method}

In order to find answers to the questions determined in accordance with the purpose of the research, it was considered appropriate to conduct a descriptive field research based on semi-structured interview technique. In semi-structured interviews, there is a general plan already designed for the study, the researcher can change the questions, despite the predesigned ones, according to the course of the interview, make certain changes in the content without deviating from the main concept of the research, and address open-ended questions to interviewees (Güler et al., 2015, p.115). Therefore, by taking the subject of the research into account, it was considered that it would be important to ask 
open-ended questions to participants when deemed necessary by the researcher, in addition to the interview form prepared in advance, in the process of determining the motherhood models adopted by women within the family and their tendencies to make use of digital communication media.

\section{Study Group}

The study aims to make a comparison, based on different motherhood models developed by Cowdey and Knudson-Martin (2005). In this regard, it was considered necessary to take the sample selection criteria used by the researchers in their own studies, in order to preserve the validity of criteria related to two motherhood models in question. Therefore, the participants of the study were first selected among those, from whom most answers can be received. Also, all the participants included in the study are individuals, who have heterosexual marriages and undertake parenting roles and responsibilities within the family. In addition, in order to present a profile of the participants, the economic status of the individuals included in the study was selected as the upper-middle class. As per the aim of the research, the participants' access to internet connection and possession of smart phones are among the criteria taken into account.

On the other hand, it is seen that, all the participants in the studies carried out by Cowdery and Knudson-Martin (2005) have children who are younger than 5 years old. However, the participants in this study were selected from individuals, whose children's age range is between 0-14 years old, so that the way, in which women participate in digital communication processes for their motherhood roles are presented with greater variety, and how women with children of different age ranges participate in digital media can be compared. For the same reason, attention was paid to ensure that demographic variables such as the educational background, occupation of the participants show diversity. In qualitative research, it is more important to reach individuals who can answer research questions best than the representation of the population. Therefore, this is closer to sampling methods used for qualitative purposes (Yıldırım, 2013, p.290-291). To that end, researchers reached suitable participants by using snowball sampling, in accordance with the criteria for the study. Furthermore, attention was paid to ensure that the number of participants adopting two different motherhood models, was equal, and the interviews ended when it was decided that sufficient amount of responses were collected with the interview questions, and the number of participants and data collected by means of the participants were expanded until a saturation point is reached. When the number of participants in both groups became equal, interviews were halted, yielding the interviewing of 16 women in total, 8 participants from each group. The table showing the demographic data of the participants included in the study are given in the table below: 
Table 1: Demographic distribution of participants

\begin{tabular}{|c|c|c|c|c|c|c|c|}
\hline \multirow[b]{2}{*}{ Name } & \multirow[b]{2}{*}{ Age } & \multirow[b]{2}{*}{ Educational Status } & \multirow[b]{2}{*}{ Occupation } & \multirow[b]{2}{*}{ Number of } & \multicolumn{3}{|c|}{ Child's Age } \\
\hline & & & & & 1st & 2nd & 3nd \\
\hline S.G. & 42 & High School & Housewife & 2 & 14 & 10 & - \\
\hline F.Ö. & 29 & Graduate Degree & Psychologist & 1 & 2 & - & - \\
\hline H.M. & 41 & $\begin{array}{l}\text { Undergraduate } \\
\text { Degree }\end{array}$ & $\begin{array}{l}\text { Manager in a private } \\
\text { company }\end{array}$ & 1 & 12 & - & - \\
\hline i.A. & 31 & Primary School & Housewife & 1 & 6 & - & - \\
\hline A.Ç. & 40 & Primary School & Housewife & 3 & 14 & 12 & 9 \\
\hline N.Ç. & 37 & Primary School & Housewife & 2 & 14 & 11 & - \\
\hline H.K. & 37 & University & $\begin{array}{l}\text { Personnel in a private } \\
\text { company }\end{array}$ & 1 & 12 & - & - \\
\hline H.M. & 39 & University & $\begin{array}{l}\text { Manager in a private } \\
\text { company }\end{array}$ & 1 & 13 & - & - \\
\hline T.A. & 33 & Doctorate & Academician & 1 & 8 & - & - \\
\hline B.B. & 38 & Graduate Degree & Business owner & 2 & 13 & 7 & - \\
\hline Z.E. & 34 & University & Business owner & 1 & 2 & - & - \\
\hline S.i. & 37 & University & $\begin{array}{l}\text { Expert in a private } \\
\text { company }\end{array}$ & 1 & 4 & - & - \\
\hline H.Ü. & 42 & University & $\begin{array}{l}\text { Manager in a private } \\
\text { company }\end{array}$ & 2 & 13 & 9 & - \\
\hline E.T. & 43 & Doctorate & Doctor & 1 & 12 & - & - \\
\hline B.G. & 36 & Graduate Degree & $\begin{array}{l}\text { Expert in a private } \\
\text { company }\end{array}$ & 1 & 3 & - & - \\
\hline S.B. & 43 & University & Business owner & 1 & 13 & - & - \\
\hline
\end{tabular}

Various questions based on the basic characteristics of different motherhood models were addressed to the participants in order to determine which motherhood model participants adopt in addition to their demographic features. Participants were then divided into two different groups, according to their responses to the questions. There is no doubt that the entirety of practices, which all women adopt or are pushed to adopt throughout their undertaking of the role of motherhood, is specific. However, all practices that are categorized as motherhood models correspond with the roles, which are assumed actively by women within the family. From this point of view, domestic practices women assume via their daily motherhood experiences, as relayed by them, are matched with Cowdery and Knudson-Martin's (2005) criteria to describe motherhood model at this stage of the study. Accordingly, the table which shows the motherhood models that participants belong according to the basic characteristics of different motherhood models found in their own family structures. 
Table 2: Distribution of participants according to the motherhood model they adopt

\begin{tabular}{|c|c|c|c|c|c|c|c|c|c|c|c|c|c|c|c|c|c|}
\hline & $\begin{array}{l}\dot{j} \\
\dot{\omega}\end{array}$ & : & $\sum_{i}^{\dot{X}}$ & 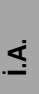 & $\begin{array}{l}\dot{\leftrightarrow} \\
\dot{\alpha}\end{array}$ & $\begin{array}{l}\dot{U}_{n} \\
\dot{z}\end{array}$ & 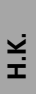 & $\sum_{i}^{\dot{X}}$ & $\stackrel{\leftrightarrow}{\leftarrow}$ & $\stackrel{\oplus}{\infty}$ & 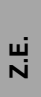 & $\bar{v}$ & : & 亡ே & ف & $\stackrel{\oplus}{\infty}$ \\
\hline \multirow{4}{*}{ 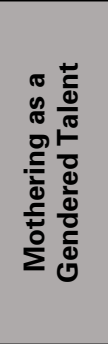 } & $\begin{array}{c}\text { Mothers have a } \\
\text { natural connection and } \\
\text { knowledge }\end{array}$ & + & + & + & + & + & + & + & + & - & - & - & - & - & + & - & - \\
\hline & Fathers stepped back & + & + & + & + & + & + & + & + & - & - & - & 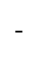 & - & - & 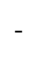 & \\
\hline & $\begin{array}{l}\text { Mothers organized } \\
\text { time around children }\end{array}$ & + & + & + & + & + & + & + & + & - & - & + & - & - & - & - & - \\
\hline & $\begin{array}{l}\text { Mothers took continual } \\
\text { responsibility }\end{array}$ & + & + & + & + & + & + & + & + & - & - & - & - & - & - & - & - \\
\hline \multirow{5}{*}{ 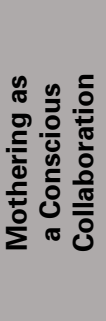 } & Shared responsibility & - & - & - & - & - & - & - & - & + & + & + & + & + & + & + & + \\
\hline & $\begin{array}{l}\text { Compensated for } \\
\text { biological differences }\end{array}$ & - & - & - & - & - & - & - & - & + & + & + & + & + & + & + & + \\
\hline & Fathers took on tasks & - & - & + & - & - & - & - & - & + & + & + & + & + & + & + & + \\
\hline & Open to learning & - & + & + & - & - & - & - & - & + & + & + & + & + & + & + & - \\
\hline & $\begin{array}{l}\text { Mothers did not } \\
\text { intervene }\end{array}$ & - & - & - & - & - & - & - & - & + & + & + & + & + & + & + & + \\
\hline
\end{tabular}

\section{Data Collection Tool}

Within the scope of this study, aiming to reveal the differences between how women participate in digital communication processes and make use of digital means of communication according to the motherhood model they adopt, it was considered necessary to determine the motherhood model participants adopt first. For this reason, the interview form was prepared in two stages. In the first stage of the form, in addition to questions intended for determining the demographic data of the participants, questions developed by Cowdery and Knudson-Martin (2015) based on the basic criteria that define different motherhood models (for mothering as a gendered talent: partners believe mothers have natural connection, fathers step back, mothers organize time around children, mothers take continual responsibility; for mothering as a conscious collaboration: compensated for biological differences, fathers took on tasks, open to learning, mothers did not intervene) were used. Researchers hence attempted to determine which motherhood model participants adopt first. In the second stage of the form, participants were asked questions about how they made use of digital communication tools for motherhood roles, for which purposes they used social media accounts and which mobile applications they preferred. Also, attention was paid to ensure that questions in the interview form have the simplest language possible. After the interview questions were prepared, the form was given its final form by consulting to three specialists on the subject. 


\section{Validity and Reliability}

Ensuring validity and reliability is of great significance in the process of categorizing and analysing the answers collected from the participants. In this regard, researchers had an exchange of ideas with two academicians, who have expertise in data collections for internal validity. Data analysis was controlled and compared with literature and similar research analysis. By means of this comparison, it was observed that findings are consistent with the literature and contributed to achieving internal validity. For external validity, statements of participants, who were interviewed during the preparation of the research report, were directly quoted. In addition, usage of purposeful sampling and achieving the aim of reflecting the research subject as a whole, despite the fact that themes are different, contributed to external validity (Yıldıım, 2013, p.13).

In order to achieve internal reliability within the scope of this study, data obtained from participants was recorded, joint interview protocol was applied in the interviews, data was collected under common headings and results were collected. Additionally, making use of theoretical background of the study in interview data analysis phase and the way these questions formed the relevant themes of the study to the extent that they are supported by research data, were other influencing factors that ensured internal reliability. Researchers paid attention to ensure that the research process was first explained in detail, in order to achieve external reliability for the study. Also, findings obtained were supported by quoting the opinions of participants, while different opinions in the collected data were not ignored and excluded. Finally, two academicians, who specialized in this field, checked the codes and themes found on the basis of data and reviewed the comments inferred, as a result of analyses.

\section{Data Collection and Analysis}

Statements of participants were recorded with both a sound recorder and by means of note-taking techniques during semi-structured interviews, conducted with the participants. Each interview was conducted face-to-face, continued for a period of 25-30 minutes and completed between the dates of 05/03/2018 and 14/04/2018. Later, statements of participants were transcribed and content analysis and descriptive analysis techniques were used for the analysis of collected data. Codes, themes and sub-themes were defined by means of content analysis technique. On the other hand, direct quotations were used by means of descriptive analysis technique, in order to reflect the opinions of interviewees or observed individuals in a remarkable manner (Yıldırım and Şimşek, 2011, p.224). Themes and sub-themes found as a result of data analysis are given below: 
Table 3: Themes and sub-themes found as a result of data analysis

\begin{tabular}{cl}
\hline \multicolumn{1}{c}{ Age of child } & 0-3 age range \\
& 3-14 age range \\
Mother-Child Interaction & Entertaining children \\
& Communicate with children \\
& Searching information about nurturing \\
Usage of social media & Get recommendation about household works \\
& Get recommendation and information about variety needs \\
Usage of mobile application & For daily requirements \\
& For daily requirements and perinatal process \\
\hline
\end{tabular}

Child's Age: When statements of participants were analysed, it was observed that age range is the most important factor in terms of determining how participants make use of digital communication tools. Accordingly, as far as the ways mothers adopting both different and same motherhood models make use of digital communication is concerned, it can be suggested that this varies according to the age range of the child. Two important age ranges that distinguish the statements of participants from others, were determined as 0-3 and 3-14, while these two age ranges were accepted as two sub-themes. It is observed that digital communication tools are regarded by participants with children of younger ages, while participants with children of older ages consider it as a more important requirement for communicating with their children.

Mother-child interaction: Another prominent theme in the statements of the participants was the idea that the basic purpose of using digital communication tools in parenting process is to ensure interaction between the mother and the child. On the other hand, three sub-themes were found, based on women's tendencies to use digital communication tools in the interactive process with their children. Women use digital communication tools for entertaining the child, communicating with the child and searching for information about childcare.

Usage of social media: One of the themes observed in the analysis of participants' statements was the usage of social media. Social media usage tendencies of women, who participated in the study, differ according to the motherhood model they adopt. Usage of social media is divided into two sub-themes, namely, getting suggestions about domestic works and getting information and suggestions about other various needs.

Usage of mobile applications: The final theme observed in the analysis of participant statements was the usage of mobile applications. It was found that the 
motherhood models participants adopted caused a difference in their tendencies to use mobile applications. On the other hand, usage of mobile application is divided into two sub-themes; namely, usage for daily needs and usage during pregnancy.

\section{Findings}

Findings on participants' opinions about their use of digital communication tools and their tendencies of using social media and mobile applications are presented below.

\section{Preferences of Mothers in Using Digital Communication Tools}

Various questions about how they make use of digital communication tools were asked to participants, who adopt two different motherhood models in the study. These include questions about the purposes women participate in digital communication, and how digital communication tools make their daily lives easier within the framework of motherhood roles. Accordingly, among the majority of women who adopt motherhood as a gendered role, those with children of older ages stated that they use digital communication tools to be in contact with their children, while mothers with children of younger ages stated that they use these digital communication tools to entertain their children.

"I generally use it for being in touch with my children. We communicate about family issues or I talk to my children on our Whatsapp groups. We have various Whatsapp groups, for instance, the group for me and my daughters, another group with the father, and another one with grandmother and grandfather. So we keep in touch in all of these groups." (S.G.)

"We are texting our children on Whatsapp very frequently. Most of all, we use it to ask questions to each other when we cannot be together in person. For instance, when my daughter is about to buy something, she takes the photo of the product and sends it when I am not with her. In this way, I don't even have to ask where the kids are or what they are doing." (A.Ç.)

"I mostly exchange messages with my children. I can follow my children. I can check where they are, how they are doing, whether they went to school. If they need anything... For such purposes. I can reach my children far more easily and quickly. Therefore, as a mother, I can say that it makes my life easier. For instance, when my child forgets a homework or a lesson note at home, I can instantly take its picture and send it." (H.M.)

"I use it the most when I am entertaining my child. I open a cartoon from YouTube, he/she watches it while I am feeding him/her so he/ she stops crying. That's why I can say that it serves quite well for me." (F.Ö.) 
As far as the statements of women, who adopt motherhood role as a collaboration are concerned, it is observed that participants with children of older age may use digital communication tools in order to be in contact with their children and find information according to the needs of both their children and themselves; while participants with children of younger age use digital communication tools to entertain their children:

"I use it especially for entertaining my child. There are videos, which show several advertisements in a sequence. Advertisements spark their interest a lot. I open them especially when I am feeding my child or when he/she is moody." (S.i.)

"We open them for attracting our child's attention to something. For instance, we give it when he/she cries too much. But this has also become a problem, because now she brings the phone and asks us to open it. (...) I sometimes look for baby food recipes or follow blogs our YouTube videos, which share post pregnancy care recommendations." (B.G.)

"When I was pregnant, I was following blogs or reading the comment written by others when I had any health problems." (Z.E.)

On the other hand, another important aspect that shows the difference between the statements of participants is the fact that, contrary to participants who adopt the other motherhood model, participants, who regard motherhood as a gendered talent, consider digital media tools a medium, where they can get information about motherhood roles. In this sense, it can be said that women, who adopt motherhood as a conscious collaboration, do not only benefit from digital communication tools for childcare and relevant supervision, but also evaluate them as media, from whence they can access information. Therefore, it would not be wrong to mention the diversity in ways of utilization of digital communication media throughout mothers' interactions with their children, depending on the motherhood model they adopt or are pushed to adopt.

\section{Mothers' Tendencies to Use Social Media}

Participants who adopt two different motherhood models were asked questions about which social media accounts they prefer and how they use these accounts in the context of motherhood roles. Accordingly, it was found that majority of women who adopt motherhood as a gendered role have Instagram, followed by Facebook, Twitter and Pinterest. All of the participants, who use Instagram actively, stated that they use Instagram in order to get various suggestions about domestic works in the process of raising their children by communicating with their friends by means of their accounts.

"I use Instagram the most. We keep in touch with my children on Instagram. I can see the photos they share, and where they are. We send photos to each other on Instagram. I also communicate with 
my friends, I get their opinions for such things as recipes, house decoration and hosting guests." (N.Ç.)

"I only use Instagram. I follow accounts, which provide useful information about clothes, flower care works, craftworks and domestic works on Instagram. I implement what I see on such pages. For instance, I take the recipe of a meal or cake, and prepare it myself. I share the meals I cook at home. (...) I have friends from other cities, even those who are living in Germany on Instagram. We follow each other and always keep in touch." (A.Ç.)

"I use Instagram. I check Pinterest occasionally. But I am not a very active user on Pinterest. I usually use it for forming opinions. For instance, I prepared many ornaments and gave gifts to the guests for my child's first birthday, based on the photos I saw on Pinterest and Instagram." (F.Ö.)

"I generally use it for my home. If there is a suggestion about my home, I check that out. If it is practical, I apply it myself. I have tried something like a stain remover, for example. If I like it, I share it with my friends too. I also use it for recipes. I even send it to my kids sometimes. Should I look this tonight or should I buy something that I like." (N.Ç.)

"I follow the agenda. Recipes, decorations. For example, there are some accounts that give decoration ideas about houses or offer presentation suggestions, sometimes I shop from where they suggest and look. I check what celebrities are doing." (H.K.)

The majority of participants, who adopt motherhood role as a collaboration, also stated that they use Instagram and Facebook actively. Twitter and Pinterest are also among the other social media accounts preferred by those participants. Participants' purposes of using social media accounts can be explained as follows: receiving information about their friends, finding suggestions about domestic works, sharing their ideas about various subjects and announcing information and news about themselves and their children to their friends. Some of the statements of participants, which come to the forefront among others, are given below:

"I use Instagram actively especially for business. But other than that, I also use it for keeping in touch with my friends, sharing news about myself, my family and other things in my life with them and announcing events, developments that I approve or disapprove. I guess it is a kind of habit from work. I share various recipes and various recommendations about home decoration and life. I mean, I can say that I both follow pages and share things myself." (B.B.) "I use Instagram, I also have a Facebook account but I haven't used it in quite a while. I follow accounts which give recipes, sell products 
such as clothes or jewellery or accounts which provide advice that may make everyday life easier." (S.i.)

"I use Facebook and Instagram. I mostly share photos on Facebook. I watch the videos my friends share or read articles, which provide information on certain subjects. (...) Sometimes, Facebook reminds me of the baby photos of my children, which I had shared in the past. Like 'You had shared this 4 years ago'. This is quite a good feature, you can use it like a personal collection. (...) On the other hand I follow foreign accounts on Instagram. I like accounts, which provide practical advices about domestic works or daily life." (H.Ü.) "I have Facebook and Instagram accounts. I use both of them, but I spend more time on Instagram. I follow the accounts of many celebrities, and check some of the magazine accounts, and accounts of those who give make-up recommendations. As a matter of fact, I can say that I can find whatever I am looking for. There are even accounts, which rebroadcast short TV series. (...) I am not following many of them now, but I was following some foreign accounts during my pregnancy period. There were accounts, which shared developments related to specific stages of pregnancy on a daily basis. I still check them, but not as frequent as I did in the past." (S.B.)

As far as social media accounts preferred by participants, who adopt different motherhood models and their purposes of using these social media accounts is concerned, it is observed that participants, who adopt both motherhood models, use their Instagram accounts very actively. While it is observed that women, who adopt motherhood as a gendered role consider their Instagram accounts as a platform on which they follow the contents shared and get various suggestions and ideas about domestic works; participants, who adopt motherhood as a collaboration follow content on their Instagram and Facebook accounts are more diverse. Another difference between the participants is that women, who adopt motherhood role as a collaboration, state that they produce content on their social media accounts. Thus, the evaluation of mothers' statements regarding their social media usage reveals that the adopted motherhood model differentiates the manner, in which mothers take part in social media. Accordingly, mothers, who adopt motherhood as a gendered talent, state that they follow digital content more and receive suggestions about recipes, home decoration, flower gardening and stain removal. At this point, it would not be erroneous to claim that the social media content, used for motherhood practices are also consumed in line with the gender role, in the event of the women's adoption of the type of motherhood role that is in accordance with the gender role. On the other hand, mothers, who adopted motherhood as a collaboration appear to consume digital content, in addition to using social media to acquire information and suggestion in different topics. From this vantage point, it is possible to posit 
that women, who share motherhood with their spouses in a division of labour, diverge from consuming digital content, according to the gender roles, which are deemed suitable for them, and produce their own content, concerning their own motherhood practices.

\section{Mothers' Tendencies to Use Mobile Applications}

Participants, who adopt different motherhood models were asked questions about whether they utilized various mobile applications within the framework of their motherhood roles, and for which needs they prefer the mobile applications they use. Accordingly, it was observed that all women, who adopt motherhood as a gendered role, use the mobile applications of their social media accounts. Participants also stated that they use mobile applications of certain shopping and discount websites, mobile banking applications and applications of airline companies.

"Yes, I use mobile applications. I mostly use shopping applications and for business, airline applications." (H.M.)

"I do not use applications much. I use the mobile applications of banks and applications of airline companies. I also check applications of shopping sites from time to time." (F.Ö.)

On the other hand, all participants, who adopt motherhood as a collaboration, stated that they use mobile applications for various needs. In addition to mobile applications of shopping and discount websites, banks and airline companies, there are various applications, which women use for tracking the developments in their own bodies and their babies during pregnancy, for playing lullabies for their babies, following their weight and calorie values, navigation purposes and travelling. Accordingly, some of the remarkable statements made by the participants about the mobile applications they use are given below:

"I used mobile applications a lot both before and during my pregnancy. There are various applications, which calculate ovulation times before pregnancy, I used such applications a lot. Afterwards, I used applications, which provide information about the development of the baby on a weekly basis. It sent notifications about the development phase of the baby every week. Even my husband downloaded it. Now I use lullaby applications for the baby. There are also applications, giving advice about the baby. I also use them. Such applications give advice about where to buy summer clothes for the baby or which baby food can be prepared for which vegetable etc." And for myself, I use the applications of shopping sites, airline companies and travel applications." (B.G.)

There are shopping applications of stores, which sell children's products and applications that give advices about nutrition. I use such applications, although not very frequently. I also used 
pregnancy calendar applications, when I was pregnant. It gave information about the development of the baby and the weeks, on which mothers must feed the child with which vitamins." (Z.E.)

"I used mobile applications during my pregnancy the most. An application provided information about the developmental stages of the baby throughout my pregnancy period. It also informed me about my emotional and physical condition, what I would go through and the condition of the baby during that specific week. Both I and my husband had bought its premium version. (...) Now that the children have grown up, I do not use any applications related to them. I now use applications that count your steps, calculate calories or the shopping applications of some sites." (T.A.)

When the applications preferred by participants, who adopt different motherhood models, and their aims of using these mobile applications are evaluated, it is observed that women, who adopt motherhood as a gendered talent, do not use mobile applications actively. Mobile applications of some shopping and discount web sites, banks and airline companies are among the applications they use. On the other hand, it is observed that women, who adopt the other motherhood model, make use of mobile applications more actively, and the applications they use show quite the variety. Therefore, it can be suggested that participants, who adopt different mothering models, use mobile applications differently and for different purposes. It is also observed that these participants use mobile applications more actively before and during pregnancy. Thus, it can be claimed that mothers, who assume motherhood as a collaboration, use mobile applications relatively more actively than others, and utilization of mobile applications differ, according to the adopted motherhood model, apart from the intensive usage of mobile applications during pregnancy or immediately after the birth.

\section{Conclusion}

The study aims to analyse the digital communication process involvement practices of women, who take part in these processes and consume various digital content within the context of motherhood practices comparatively. To that end, participants were divided into two groups according to the mothering model they adopt, and questions concerning their ways of using digital media, and tendencies to use social media and mobile applications, were addressed to the participants. An evaluation of the research findings displays that the most significant determinant for the way female participants, who adopt different motherhood models, make use of digital communication tools, is the age range of their children. While participants with children of younger ages prefer digital communication tools to entertain their children, participants with children of older ages use digital communication tools, in order to receive information about their various needs, related to motherhood role. In this regard, research results are of importance, since they reveal how women, adopting different motherhood 
models, make use of digital communication tools, which varies according to the age range of their children. Another aspect that shows difference between the statements of participants is the fact that, contrary to participants who adopt the other motherhood model, participants, who regard motherhood as a gendered talent, consider digital media tools a medium, where they can get information about motherhood roles. Within the framework of this observation, it can be suggested that women, who adopt motherhood as a collaboration, are aware of the fact that digital media is an environment, which provides information, in accordance with motherhood roles.

When social media accounts, preferred by mothers, who adopt different mothering models, and their purposes of usage of these social media accounts, are analysed, it is observed that participants, who adopt both mothering models mostly use Instagram. It can also be suggested that women, who assume mothering role as a collaboration, also use their Facebook accounts actively, much like Instagram. On the other hand, it is observed that women, who take on motherhood as a gendered role, prefer following the content shared on their social media accounts, and consider social media as a platform, on which they get various suggestions and opinions about domestic chores. It may be posited that women, who adopt motherhood as a collaboration, use their social media accounts more actively; because the content subjects, followed by women, who adopt motherhood as a collaboration model, show more diversity. Another difference observed between the participants was that, mothers, who adopt motherhood role as a collaboration, stated that they create content (such as sharing their opinions, announcing information and events) on their social media accounts.

When the applications preferred by participants, who adopt different motherhood models, and their aims of using these mobile applications are evaluated, it is observed that women, who adopt motherhood as a gendered talent, do not use mobile applications actively; but they use applications such as shopping, banking and airline companies, which meet their daily needs. On the other hand, it was found out that women, who adopt the other motherhood model, make use of mobile applications more actively, and the applications they use shows quite the variety. It is observed that women, who adopt this model, prefer mobile applications, related to pre-natal and post-natal periods at rather higher levels. 
Table 4: Digital media tools usage preferences of women, who adopt motherhood as a gendered talent
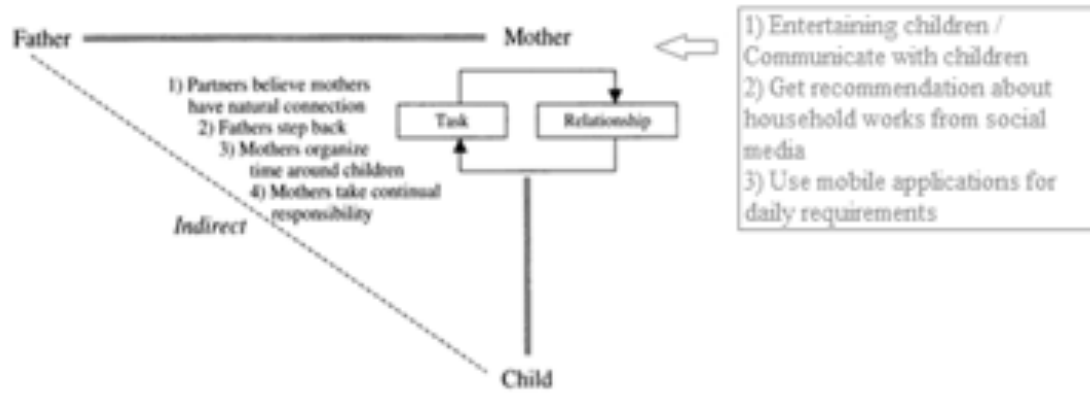

Therefore, it can be suggested that preferences of women, who adopt motherhood as a conscious collaboration, regarding their usage of both social media accounts and mobile applications, show that they participate in digital communication process more actively. Also, the finding which indicates the fact that participants who adopt this motherhood model use mobile applications mostly during pre-natal and post-natal periods is important, in that it supports the results of previous researches (Hearn et.al. 2013; Johnson, 2014; Kraschnewski, 2014; Lagan et.al, 2010; Lupton, 2016; Lupton and Pedersen, 2016; O'Higgins et.al. 2015).

In addition, some of the participants, who adopt this motherhood model, also stated that these mobile applications related to pregnancy are also used by their partners. This statement is considered important in that it indicates how participants share the motherhood role in collaboration with their partners, and confirms the categorization of motherhood model, in which participants, who adopt this motherhood model are included.

Table 5: Digital media tools usage preferences of women, who adopt motherhood a conscious collaboration
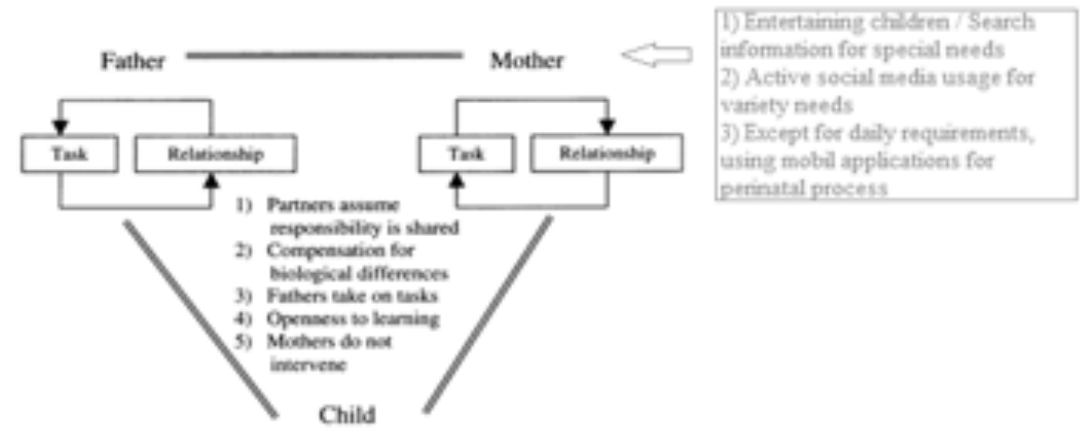
Consequently, it is considered that the study takes the distinction between mothering models suggested by Cowdery and Knudson-Martin (2005) one step further by investigating it, based on the ways, in which mothers take part in digital communication; and also provide a new perspective, in terms of revealing the ways these different mothering models participate in digital communication processes, as well as their tendencies to use digital media tools.

\section{References}

Ammari, T., Kumar, P., Lampe, C. And Schoenebeck, S. (2015). Managing Children's Online Identities: How Parents Decide What To Disclose About Their Children Online. Proceedings Of The 33rd Annual ACM Conference On Human Factors In Computing Systems, ACM Press: New York, P.1985-1904.

Ammari, T., Morris, M. And Schoenebeck, S. (2014). Accessing Social Support And Overcoming Judgement On Social Media Among Parents Of Children With Special Needs. Proceedings Of AAAI International Conference On Weblogs And Social Media, P.22-31.

Ammari, T. And Schoenebeck, S. (2015). Understanding And Supporting Fathers And Fatherhood On Social Media Sites. Proceedings Of The 33rd Annual ACM Conference On Human Factors In Computing Systems, New York, P.1905-1914.

Arendell, T. (2000). Caregiving And Investigating Motherhood: The Decade's Scholarship. Journal Of Marriage And The Family, 61, 199-213.

Archer, C. And Kao, K.T. (2018). Mother, Baby And Facebook Makes Three: Does Social Media Provide Social Support For New Mothers?. Media International Australia, 168(1), 122-139.

Baber, K. And Allen, K. (1995). Women In Families: Feminist Reconstructions. New York: Guilford.

Badinter, E. (1981). Mother Love: Myth And Reality. Motherhood In Modern History. New York: Macmillan.

Bal, S. (2014). Reklamların Eskimeyen Yüzü "Muhteşem Annelik". Ilef Dergisi, 1(2), 59-85.

Barak-Brandes, S. (2017). Ideologies Of Motherhood In Contemporary Israeli TV Commercials. Communication, Culture \& Critique, 10, 58-75.

Bartholomew, M.K., Schoppe-Sullivan, S.J., Glassman, M., Kamp Dush, C.M. And Sullivan, J.M. (2012). 'New Parents' Facebook Use At The Transition To Parenthood. Family Relations, 61(3), 455-469.

Bernard, J. (1974). The Future Of Motherhood. New York: Dial Press.

Brady, E. And Guerin, S. (2010). Not The Romantic, All Happy, Coocy Coo Experience: A Qualitative Analysis Of Interactions On An Irish Parenting Web Site. Family Relations, 59(1), 14-27. 
Budig, M.J., Misra, J. And Boeckmann, I. (2012). The Motherhood Penalty In Cross-National Perspective: The Importance Of Work-Family Policies And Cultural Attitudes. Social Politics, 19(2), 163-193.

César, F., Costa, P., Oliveira, A. And Fontaine, A. M. (2018). “To Suffer In Paradise": Feelings Mothers Share On Portuguese Facebook Sites. Frontiers In Psychology, Available Online: Https://Bit.Ly/2qhzOdg

Christopher, K. (2012). Extensive Mothering: Employed Mothers' Constructions Of The Good Mother. Gender \& Society, 26(1): 73-96.

Collin, F. And Laborie, F. (2015). Annelik. In. H. Hırata, F. Laborie, H. L. Doare, And D. Senotier (Eds.), Eleştirel Feminizm Sözlüğü (Pp.39-45). Ankara: Dipnot Yayınları.

Cowdery, R.S. And Knudson-Martin, C. (2005). The Construction Of Motherhood: Tasks, Relational Connection, And Gender Equality. Family Relations. 54 (3), 335-345.

Drentea, P. And Moren-Cross, J. (2005). Social Capital And Supporton The Web: The Case Of Internet Mother Site. Sociology Of Health \& IIInes, 27(7):920-943.

Dreuth, L. (2003). A Priori Vs. Experimental Models Of Parenting In The Assessment Of Mothering. Atlantis: Critical Studies In Gender, Culture \& Social Justice, 28(1): 72-79.

Dolan, B. (2013). Report Finds Pregnancy Apps More Popular Than Fitness Apss. Mobile Health News. Available Online: Https://Bit.Ly/2OH3n15

Dworkin, J., Connell, J. And Doty, J. (2013). A Literature Review Of Parents' Online Behavior. Cyberpsychology: Journal Of Psychosocial Research On Cyberspace, 7(2): 1-12.

Eagle, R.B. (2019). " "Have You Tried Ginger?": Severe Pregnancy Sickness And Intensive Mothering On Instagram. Feminist Media Studies, 19(5): 767-769.

Elvin-Nowak, Y. And Thomsson, H. (2001). Motherhood As Idea And Practice: A Discursive Understanding Of Employed Mothers In Sweden. Gender \& Society, 15, 407-428.

Erdoğan, T. (2008). Nancy Chodorow'un Düşüncesinde Toplumsal Cinsiyet Organizasyonunun Merkezi Unsuru Olarak Annelik. Aile Ve Toplum. 10(4): 73-82.

Gibson, L. And Hanson, V.L. (2013). Digital Motherhood: How Does Technology Help New Mothers?. Proceedings Of The SIGCHI Conference On Human Factors In Computing Systems, New York: ACM Press, P.313-322.

Glenn, E.N. (1994). Social Constructions Of Mothering: A Thematic Over-View. In. E.N. Glenn, G. Chang, And L. R. Forcey (Eds.), Mothering, Ideology, Experience, And Agency (Pp.1-39). New York: Routledge.

Glenn, E.N., Chang, G. And Forcey, L.R. (1994). Mothering: Ideology, Experien- 
ce, And Agency. New York: Routledge.

Güler, A., Halıcıoğlu, M.B. And Taşğın, S. (2015). Sosyal Bilimlerde Nitel Araştırma. Ankara: Seçkin Yayıncılık.

Hays, S. (1996). The Cultural Contradictions Of Motherhood. New Heaven: Yale University Press.

Hearn, L., Miller, M. And Fletcher, A. (2013). Online Healthy Lifestyle Support In The Perinatal Period: What Do Women Want And Do They Use It?. Australian Journal Of Primary Health, 19(4), 313-318.

Jang, J. And Dworkin, J. (2014). Does Social Network Site Use Matter For Mothers?: Implications For Bonding And Bridging Capital. Computers In Human Behavior, 35, 489-495.

Johnson, S. (2014). Maternal Devices, Social Media And The Self-Management Of Pregnancy, Mothering And Child Health. Societies, 4(2), 330-350.

Johnson, S. (2015). Intimate Mothering Publics: Comparing Face-To-Face Support Groups And Internet Use For Women Seeking Information And Advice In The Transition To First-Time Motherhood. Culture, Health, \& Sexuality, 17(2), 237-251.

Johnston, J. And Swanson, D.H. (2003). Invisible Mothers: A Content Analysis Of Motherhood Ideologies And Myths In Magazines. Sex Roles. 49(1-2): 21-33.

Keelan, J., Pavri-Garcia, V., Tolimson, G. And Wilson, K. (2007). Youtube As A Source Information On Immunization: A Content Analysis. JAMA, 298(21), 24822484.

Kraschnewski, J.L., Chuang, C.H., Poole, E.S., Peyton, T., Blubaugh, I., Pauli, J., Feher, A. And Reddy, M. (2014). Paging "Dr. Google": Does Technology Fill The Gap Created By The Prenatal Care Visit Structure? Qualitative Focus Group Study With Pregnant Women. Journal Of Medical Internet Research, 16(6): E147.

Lagan, B.M., Sinclair, M. And George Kernohan, W. (2010). Internet Use In Pregnancy Informs Women's Decision Making: A Web Based Survey. Birth, 37(2), 106-115.

Longhurst, R. (2016). Mothering, Digital Media And Emotional Geographies In Hamilton, Aotearoa New Zealand. Social \& Cultural Geography, 17(1), 120-139.

Lupton, D. (2016). The Use And Value Of Digital Media For Information About Pregnancy And Early Motherhood: A Focus Group Study. BMC Pregnancy And Childbirth, 16(171). Available Online: Https://Bit.Ly/2D03f4r

Lupton, D. (2017). "It Just Gives Me A Bit Of Peace Of Mind": Australian Women's Use Of Digital Media For Pregnancy And Early Motherhood. Societies, 7(3): 3-15.

Lupton, D. And Pedersen, S. (2016). An Australian Survey Of Women's Use Of 
Pregnancy And Parenting Apps. Women And Birth. 29(4), 368-375.

Madge, C. And O'Connor, H. (2006). Parenting Gone Wired: Empowerment Of New Mothers On The Internet?. Social \& Cultural Geography, 7(2), 199-220.

Marshall, H. (1991). The Social Construction Of Motherhood: An Analysis Of Childcare And Parenting Manuals. In. A. Phoenix, A. Woollett, \& E. Lloyd (Eds.). Gender And Psychology Motherhood: Meanings, Practices And Ideologies (Pp.6685). Thousand Oaks: Sage Publications.

Mcdonagh, E. (2002). Models Of Motherhood In The Abortion Debate: Self-Sacrifice Versus Self-Defence. In. D.L. Dickenson (Ed.). Ethical Issues In Maternal-Fetal Medicine (Pp.21-232). Cambridge: Cambridge University Press.

Miller, T. (2005). Making Sense Of Motherhood: A Narrative Approach. Cambridge: Cambridge University Press.

Morris, M.R. (2014). Social Networking Site Use By Mothers Of Young Children. Proceedings Of The 17th ACM Conference On Computer Supported Cooperative Work \& Social Computing, New York: ACM Press, P.1272-1282.

Morrison, A. (2010). Autobiography In Real Time: A Genre Analysis Of Personal Mommy Bloging. Cyberpsychology, 4(2): 1-14.

Naples, N. (1992). Activist Mothering: Cross-Generational Continuity In The Community Work Of Women From Low-Income Urban Neigborhoods. Gender \& Society, 6(3): 441-463.

O'Higgins, A., Murphy, O.C., Egan, A., Mullaney, L., Sheehan, S. And Turner, M. (2015). The Use Of Digital Media By Women Using The Maternity Services In A Developed Country. Irish Medical Journal, 108(10): 313-315.

Pedersen, S. (2014). Is It Friday Yet?: Mothers Talking About Sex Online. Cyberpsychology. 8(2), 2-4.

Pedersen, S. And Lupton, D. (2016). What Are You Feeling Right Now?: Communities Of Maternal Feeling On Mumsnet. Emotion, Space, And Society, 1-7.

Phoenix, A. And Woollett, A. (1991). Motherhood: Social Construction, Politics And Psychology. In. A. Phoenix, A. Woollett, And E. Lloyd (Eds.). Gender And Psychology. Motherhood: Meanings, Practices And Ideologies (Pp.13-27). Thousand Oaks: Sage Publications.

Ribbens, J. (1994). Mothers And Their Children: A Feminist Sociology Of Childrearing. London: Sage Publication.

Rich, A. (1995). Of Woman Born: Motherhood As Experience And Institution. New York: WW Norton \& Company.

Robinson, A., Lauckner, C., Davis, M., Hall, J. And Anderson, A.K. (2019). Facebook Support For Breastfeeding Mothers: A Comparison To Offline Support And Associations With Breastfeeding Outcomes. Digital Health, Available Online: Ht- 


\section{tps://Bit.Ly/34PO0Yb}

Schoenebeck, S.Y. (2013). The Secret Life Of Online Moms: Anonymity And Disinhibition On Youbemom. Paper Presented At The 7th International AAAI Conference On Weblogs And Social Media (ICWSM'13), Boston.

Stearney, L.M. (1994). Feminism, Ecofeminism And Maternal Archetype: Motherhood As A Feminine Universal. Communication Quarterly, 42(2), 145-159.

Tardy, R.W. (2000). "But I Am A Good Mom" The Social Construction Of Motherhood Through Health-Care Conversations. Journal Of Contemporary Ethnography, 29(4), 433-473.

Thompson, L. And Walker, A. (1989). Gender In Families: Women And Men In Marriage, Work And Parenthood. Journal Of Marriage And The Family. 51, 845871.

Thomson, E., Mosley, J., Hanson, T. And Mclanahan, S. (2001). Remarriage, Cohabitation, And Changes In Mothering Behavior. Journal Of Marriage And Family, 63(2): 370-380.

Tiidenberg, K. (2015). Odes To Heteronormativity: Presentations Of Feminity In Russian-Speaking Pregnant Women's Instagram Accounts. International Journal Of Communication, 9(13): 1746-1758.

Walker, S., Dworkin, J. And Connell, J. (2011). Variation In Parent Use Of Information And Communication Technology: Does Quantity Matter?. Family \& Consumer Sciences Research Journal, 40, 106-119.

Yam, S.S. (2019). Birth Images On Instagram: The Disruptive Visuality Of Birthing Bodies. Women's Studies In Communication, 42(1): 80-100.

Yıldırım, A. (2013). 4. Eğitim Bilimleri Araştırma Günleri Nitel Araştırma Semineri Çalışma Yaprakları. Ankara: Pegem Akademi.

Yıldııım, A. And Şimşek, H. (2013). Sosyal Bilimlerde Nitel Araştırma Yöntemleri. Ankara: Seçkin Yayıncılık.

Young, K. (2011). Social Ties, Social Networks And The Facebook Experience. International Journal Of Emerging Technologies And Society, 9(1): 20-34. 
